Article

\title{
Justice and Civil Liberties on Sex Work in Contemporary International Human Rights Law
}

\author{
Belinda Brooks-Gordon ${ }^{1, *}$, Marjan Wijers ${ }^{2}\left(\mathbb{D}\right.$ and Alison Jobe ${ }^{3}(\mathbb{C})$ \\ 1 School of Psychological Sciences, Birkbeck, University of London, London WC1E 7HX, UK \\ 2 Department of Sociology, University of Essex, Colchester CO4 3SQ, UK; mw18793@essex.ac.uk \\ 3 Department of Sociology, University of Durham, Durham DH1 3HN, UK; alison.jobe@durham.ac.uk \\ * Correspondence: b.brooks-gordon@bbk.ac.uk
}

Received: 1 October 2019; Accepted: 22 December 2019; Published: 10 January 2020

\begin{abstract}
To fulfil obligations in international law State parties have to take the issue of human trafficking seriously. The United Nations Committee on the Elimination of Discrimination Against Women (CEDAW) provides General Recommendations (GR) to member states on the interpretation of the Women's Convention. In 2018 the CEDAW Committee started to develop a GR on trafficking in women and girls in a process planned to conclude in 2020. The first stage towards this was through the publication of a Concept Note to serve as a basis for dialogue during the two-year international consultation period. The Concept Note is a vital link in a textual chain because it frames the policy problem and actively constructs its own 'documentary reality'. This article provides a critical analysis of the CEDAW Concept Note on the grounds that such analysis provides an understanding of its discursive construction of trafficking, migrant labour and sex work, by an institution responsible for international jurisprudence on human rights. Analysis of the Concept Note explores the documentary constructions including narratives that merge adult women with girls, the symbolism of exploitation, the silencing of scientific research, the elision of sex worker voices, and sex work as work. The analysis leads us to conclude that the General Recommendation should define what counts as 'exploitation', and 'forced labour', and address the growing international recognition of best evidence on the wider impact of sex work laws, in order that legal framing and constructions of sex trafficking are not erroneously used to curtail rights of sex workers.
\end{abstract}

Keywords: sex worker rights; prostitution policy; anti-sex trafficking; decriminalization; gender; social control

\section{Introduction}

One of the nine core human rights instruments is the Convention on the Elimination of All Forms of Discrimination against Women (CEDAW). Formed in 1979, it is overseen by the Committee on the Elimination of Discrimination against Women (also called CEDAW). It came into force as an international treaty in 1981 and the function of the CEDAW Convention is to bring women into the focus of human rights concerns (OHCHR 2019). It establishes an international bill of rights for women and an agenda for action by countries to guarantee the enjoyment of those rights. The Convention is a dynamic instrument that contributes to the development of international law and policy frameworks in global jurisprudence.

To guide State parties' implementation of its Convention the CEDAW Committee develops General Recommendations (GRs) on Convention obligations taking into account current issues facing women and girls. It has developed thirty-seven General Recommendations (GRs), a number of which intersect between wider Convention obligations under study and their relation to trafficking. 
In an uncertain world order concern about migration is often used in political rhetoric to curtail rights-and not just of those who migrate. The growing appreciation of the importance of understanding migration, migrant labour, and trafficking led to the CEDAW Committee decision to develop a GR on Trafficking in Women and Girls in the Context of Global Migration in order to interpret the definition, scope and expectations of States' obligations in relation to Article 6 of the Convention, ensuring that 'the human rights of women and girls are respected, protected, and fulfilled in accordance with international law'. The first stage towards developing the GR is by way of a Concept Note which serves as a basis for discussion prior to global and regional consultations. Written and oral responses were invited from civil society organisations, during a Day of General Discussion held in Geneva, Switzerland on 22 February 2019, as the first step towards global consultation in 2020. The Concept Note is therefore a link in an intertextual chain of documents using and developing shared assumptions and knowledge that create powerful documentary realities (Coffey 2014) in the definition and legal framing of trafficking. The aim of this article is to explore how this document reproduces shared assumptions, and creates others, for a particular kind of audience.

\section{Methodology}

The Concept Note (CEDAW 2018) was analysed as a case study using a discourse analysis approach drawing on Coffey (2014) to explore the language and form, the function, and the intertextuality of the document. Building on the canon of 'policy as discourse' (Fairclough 2001) and documentary critique of prostitution policy (Brooks-Gordon 2005), the procedure initially entailed analysis by the first author who also carried out a comparison of the document to other human rights based policy documents such as that by Amnesty International (2016a). At the same time the document was contrasted to those produced by the UN in relevant areas such as the International Labour Organisation (ILO) by the second author who, well versed in the linguistic repertoire of the UN, explored the network of protocols from which narratives could have been drawn.

Following the initial analysis, the policy process was engaged with in the form of written and oral evidence given at the Day of General Discussion, in a practice we call critical policy engagement. As the manuscript was revised for publication, engagement with the work of Atkinson and Coffey (2004); Prior (2008); and Prior et al. (2012) heightened the exploration of language and discourse within the Concept Note to examine further which narratives are constructed and which ideas are privileged over others, or silenced.

\section{The Concept Note}

The Concept Note is divided into six sections comprising 54 short paragraphs. The title 'Concept Note' foretells that this document is a view or belief, and one written in the linguistic register (Coffey 2014) of powerful global treaties as the reinforcing adverb in its 'authoritative guidance' for member states illustrates. The subsequent sections are numbered in Roman numerals and situate the document within its historic context and within a dense network of cross-referencing of Human Rights protocols. The short paragraphs and short subheadings belie the grandiloquent language of diplomacy where the subsequent General Recommendation (GR) is described as 'under elaboration' rather than in development or a work in progress.

The Concept Note also situates itself in the complex issue of trafficking, smuggling and economic migration by the way it defines trafficking, and immediately differentiates it from, migrant smuggling or economic migration. The document employs an array of international legal regimes and 'a human rights framework for protection during conflict and humanitarian situations' to justify its position. It sets out the rationale for the GR on trafficking in the contemporary context of global migration to argue that trafficking affects 'women and girls' disproportionately, in the paternalist rhetoric that predominates.

The document amplifies its rationale with the justificatory embellishment that 'global migration flows are unprecedented'. It presents wider forms of exploitation for which women and girls are 
trafficked, as well as emerging developments 'driving demand for trafficking and supply of victims'. Key concerns of the CEDAW Committee are also put forward to argue that trafficking is rooted inter alia in gender-based discrimination, displacement risk, links to unsafe migration channels, and gender-specific work and labour markets. The final sections of the document deal with process issues to show how the CEDAW Convention assists member States to meet their obligations under Article 6 to combat trafficking, lays out the instruments that underpin this, and describes the scope and expectations of the GR that should emerge from 'the deliberations'. The document ends with a section entitled 'Day of General Discussion' in which a list of sub-themes 'to be featured in the General Recommendations for which stakeholder input is sought' as the language of diplomacy merges into that of technocratic managerialism.

\subsection{Representations of Trafficking and the Rhetorical Economy of Sex Work}

Throughout the Concept Note particular kinds of representations are constructed in references to 'new realities', which it suggests, are the consequences of conflict or global migration. Underpinning these 'new realities' are statistics drawn from the Global Report on Trafficking in Persons (UNODC 2018), upon which the Concept Note relies for justification, in terms of the size of the 'problem' with which it aims to deal. Inspection of the UNODC (2018) Report, however, shows that countries with strong economic performance, global economics, and globalisation, all create increased migration around the world. In its representation of trafficking the Concept Note constructs a vulnerable migrant rather than an active economic one. Nor does it consider other kinds of forced labour and servitude ${ }^{1}$ which are important for understanding and capturing the complexity of trafficking.

The Concept Note omits to note that under international Human Rights law states have an obligation to provide victims of Human Rights violations with an adequate remedy ${ }^{2}$, and despite containing a network of protocols, it does not contain the ILO 2014 Forced Labour Protocol which would make this explicit (ILO 2014). It does, however, refer to the 1949 Convention for the Suppression of the Traffic in Persons and the Exploitation of the Prostitution of Others. The textual link to an obsolete, controversial, restricted (it was only ratified by a limited number of states) instrument creates a position that fails to differentiate between prostitution and trafficking; as such it negates the will and agency of women.

The 1949 Convention was overturned by, and is in contradiction with, the 2000 UN Trafficking Protocol (United Nations 2000), that clearly distinguishes between trafficking and sex work, leaving policies on prostitution to the discretion of individual states. It is also in contradiction with the objective and scope of the GR as discussed in the Concept Note, which (i) explicitly states that the future GR should focus on trafficking and not on prostitution and (ii) that it does not want to broach a political discussion on prostitution, which is undermined by referring to the 1949 Convention. In this way the document situates itself, as not just being averse to forced labour, but also averse to sexual labour.

The draft Concept Note refers to 'an increase of trafficking' and 'a majority of women and girls' 'of which the majority is for 'sexual exploitation", and that "women and girls continue to be the prime targets, especially for sexual exploitation'. The merging of 'women and girls' is a dominant discourse throughout the document which privileges a narrative of 'exploitation' and ties it closely to sex work, in a representation that contrasts to other major sources such as International Labour Organisation reports which argue that other sectors predominate:

See for example Siliadin v France, ECtHR, application no. 73316/01, 26/10/2005.

Reference should therefore have included major UN and European human rights treaties including ICCPR (1966); ICESCR (1966); ICERD (1965); ECHR (1950) and ECATHB (2005). 
'Out of the 24.9 million people trapped in forced labour, 16 million people are exploited in the private sector such as domestic work, construction or agriculture; 4.8 million persons in forced sexual exploitation, and 4 million persons in forced labour imposed by state authorities'.

(ILO 2014)

In the creation of this narrative, the Concept Note draws on large scale and largely unsubstantiated data to contradict its own main sources, the UNODC (2018), which describes the inherent problems in counting, discrepancies in states' definitions, recording systems, and the lack of availability of internationally standardized data, for example in 2017, 2015, or 2014 (UNODC 2018). The use of massive figures is a well-established convention in creating a dominant narrative of trafficking for prostitution in the 'rhetorical economy of sex industry opposition' (Phipps 2017). Given the systematic relationship between the Concept Note and the GR, a consequence of this construction is that the GR's framing may omit other sectors and purposes for which women are trafficked, especially domestic labour and marriage.

The linguistic foundations laid in the Concept Note are reinforced in the use of a 'demand' narrative, for example in 'emerging developments driving the demand for trafficking and supply of victims' and 'intensifying efforts to address the demand fostering the trafficking of women and children'. The ill-defined notion of demand (DemandAt 2017) is a well understood trope in the construction of a rhetoric that at once implies heterosexuality, men as active agents, women as passive, and an anti-sex work stance. It is at odds with scientific peer-reviewed research (for example Anderson and Davidson 2004; Day and Ward 2004; Brooks-Gordon 2008; Östergren 2017) which demonstrates that rather than a demand for the labour or services of trafficked persons, there is predominantly a demand for cheap and exploitable labour/workers without rights per se. One of the gender-based factors that put women at risk of trafficking and exploitation, is the fact that women's work in female designated labour sectors, such as domestic work, sex work and entertainment, is not or only marginally recognised as work, with the ensuing lack of labour rights and labour protections (Wijers and Lap-Chew 1999; Wijers 2015). Labour rights and labour law protections have proved to be the most successful means of protecting vulnerable workers against exploitation and abuse, yet through the symbolism of 'supply' and the repetition of references to the 'demand side of the commercial sex industry' (in para. 15, 19, 25, 27 and 52) the Concept Note employs a phrase frequently used in a targeted way against people who sell sex, and one used as a means to reduce or eradicate sex work (Phipps 2017). This is directly counter to the stated aims of the document which is to eradicate trafficking.

While 'addressing demand' is not the same as criminalising clients of sex workers (Östergren 2017), the link between criminalisation of prostitution, including of clients, and susceptibility for trafficking and other abuses should be taken into account. This is because of its ideological underpinning (i.e., radical feminism, Marxism, and religious evangelism) influenced by prohibitionist pressure groups which also 'use trafficking rhetoric and inflated figures which may also exploit migration fears and mask immigration statistics and practices' (Brooks-Gordon 2010). The document relies on the assumption that a simplistic economic model of demand-led supply or supply-driven demand is applicable to transactional sexual activity and privileges an anti sex work narrative. What is silenced is the research evidence showing the economy of sex work to be more multifarious, encompassing complex feelings of fantasy and desire that are psychological and cultural. The narrative also silences the perspective(s) of sex workers and the presence of male sex workers and transgender people in sex work.

\subsection{The Silencing of Science and of Sex Worker Voices}

A wealth of academic research and community-based evidence showing how criminalisation of sex work compromises the safety, health and human rights of people who sell sex and directly contributes to human rights abuses is ignored (Global Alliance against Traffic in Women 2007; ICRSE 2016, 2018; Fuckförbundet 2019). This includes laws that criminalise the organisation or 'promotion' of prostitution, 
the renting of housing or workspace to sex workers, living of the earnings of sex work, the selling of sex and/or the purchase of sex through a variety of different criminal offences. The impact is also seen in other laws such as immigration provisions which stipulate the suspicion of prostitution as a reason for immediate deportation like in Sweden (Fuckförbundet 2019).

Most obviously, given the emphasis on regional examples, a large systematic review of best evidence from thirty three countries by Platt et al. (2018) demonstrating the impact of criminalisation, including client criminalisation, on the health, safety and rights of sex workers was omitted. This meta-analysis showed the extent to which policing practices affect sex workers' safety, health and access to services. In addition, the impact of the ban against purchasing sex, often in the name of combatting trafficking, has been researched by a wide variety of authors, academics and NGOs, for example by Brooks-Gordon (2010), Levy (2014), Levy and Jacobsson (2014), Mai et al. (2018), and Dodillet and Östergren (2011) in various countries, including Sweden, Norway and France. A scientific canon has been silenced, as have rights-based policy frameworks by global organisations putting the narratives of sex workers, front and centre, such as that by Amnesty International (2016b).

Criminalisation often has the opposite results than that which was intended. Criminalising buyers reduces the bargaining power of sex workers, including for safe sex, makes them more dependent on intermediaries and even pimps, banishes them to dangerous and isolated areas, prevents them from reporting to the police in case of violence or other abuses, and increases stigma. There is significant evidence that sex workers continue to be criminalised and penalised by any legal framework that criminalises their clients. In Norway for example, after the criminalisation of buying sexual services, it was found that the public viewed the sellers of sex much more negatively with a resulting stigmatisation and vulnerability of the women involved. This change in attitude was the opposite of what was intended by the legislators. Similarly, in Sweden where after the criminalisation of clients a change in public opinion took place (Amnesty International 2016b).

The increase of public stigma on people who sell sex impacts on the health and wellbeing of women (Scambler and Frederique 2008) and negative attitudes towards sex work and sex workers have a manifestly detrimental impact on the well-being of sex workers. For example, in interviews by Amnesty International an officer from Pro Sentret in Norway stated: 'a lot of the women told us that every time there was a big debate about the law (in media or parliament) there would be people driving in the prostitution areas, shouting, throwing things, calling the women "dirty whores"' (Amnesty International 2016b, p. 91). It was also found that an increased percentage of sex workers report being unwantedly "felt up", called abusive terms, threatened or forced, pushed, threatened with a weapon, tugged, spat on, choked, bitten, kicked and scratched. In most cases, the perpetrator was either a random customer (67\%), or a passer-by (22\%). So, clearly, the risk of opportunistic violence on sex workers had increased but the narrative of sex workers' own voices and the wider Human Rights canon is missing from the document.

The growing international recognition that states with a decriminalized sex industry have less trafficking, is also a narrative suppressed in the Concept Note. For example, New Zealand, about which the UNODC (2018) states that: 'trafficking for forced labour was a more common form of exploitation than for sexual exploitation' (p. 67) and 'most of the victims of trafficking for forced labour were men' (p. 69). New Zealand also has better labour rights as case law from employment tribunals show, for example in DML v. M E T Enterprises $L t d$. damages of \$25,000 NZD were paid to a sex worker for inappropriate, suggestive, remarks made to her by a brothel owner. The case explicitly shows that labour rights and recourse to justice in order to exercise those rights are much greater in a decriminalized environment than any other (Brooks-Gordon 2018). Yet neither a decriminalization nor labour rights narrative are present to balance the discussion put forward in the document.

The Concept Note argues repeatedly that it aims for 'integrating a human rights approach in all anti-trafficking interventions' (para. 8, 18 and 19). This implies the protection of the human rights of all groups affected by anti-trafficking policies, laws, measures, and obligations to ensure that 
anti-trafficking measures in no way harm or undermine human rights. The underpinning narrative of the text does not, however, support this assertion.

While the document uses regional illustrations to show terrible harm, for example in citing the kidnap of 200 girls in Chibok in Nigeria, it does not use any regional examples of harm prevention. Yet, this can be done, as within nation states political parties have found in formulating policy on the issue that: "The principles that guided the policy ... included 'The harm principle', a person's inalienable right to bodily integrity, that every person should have control over their own body, equality and the avoidance of stigma and discrimination. These were underpinned by the social justice ... 'to build a fair, free and open society, in which no one shall be enslaved by poverty, ignorance, or conformity" (Brooks-Gordon et al. 2017, p. 3).

The evidence taken, and the fundamental importance of consent, led a political party in the UK to develop the policy above, and to conclude they could:

'only propose a system that is based on full realisation of sex workers' human rights and underlines the states' obligations to address them. Inevitably this includes decriminalisation as a path to harm reduction. To ensure harm reduction, people who voluntarily choose to engage in sex work would have the same employment and civil rights as any other person and be freed from discrimination by legal, health, and financial institutions'.

(Brooks-Gordon et al. 2017, p. 14)

International obligations to respect, protect and fulfil these rights as they relate to people who sell sex include the right to security of the person, the right to equal protection of the law, the right to non-discrimination, the right to health, the right to privacy and the right to housing. States that do not respect, protect and fulfil these rights as they relate to people who sell sex are not complying with their international obligations, and as Wijers (2015) has argued:

'It also means that we should not only be concerned about the human rights of trafficked persons, but also about the impact of anti-trafficking policies and measures on the human rights of other groups affected by them, in particular sex workers, migrants and refugees. With regard to the first group, there is a lot to learn from the sex workers' rights movement ... the body of research on the negative human rights impacts of anti-trafficking measures is ever growing'.

(Wijers 2015, p. 78)

The Concept Note states that 'sector-specific migration perpetuates victimization', and argues that limited job opportunities in countries of origin lead migrant women to 'end up in informal employment', and 'male-driven entertainment sectors, including in forced prostitution'. It reinforces the discursive passivity of women, of sex work as work of last resort, undertaken only through duress or force. It buttresses this narrative to argue that women and girls are 'trafficked for the purpose of sexual exploitation, including forced prostitution, sexual entertainment ... ', yet in a subsequent paragraph on 'groups most at risk' sex workers and transwomen are omitted. In the privileging of exploitation narratives what is missing is any analysis of the effects of the lack of labour protection for people in sex work, because an additional violation to women's human rights is that women not only face prosecution and punishment for irregular migration but also for involvement in sex work. In this way there is a silencing of 'consent' that has occurred in past Protocols (see Doezema 2002).

Within the Concept Note there are inherent contradictions, for example, one stated aim is to 'tackle the wide impunity enjoyed by the perpetrators of trafficking in women and girls, including by addressing the demand-side of the crime. Yet, the following discussion states that the scope of the GR will be restricted and 'It will not broach a policy discussion on the theme of prostitution'. This rhetorical sleight of hand allows the documentary construction to continue without addressing that a fundamental element of access to justice is access to an adequate remedy, including specialised 
legal aid, compensation and redress, as the Human Rights instruments upon which it could have drawn shows:

'Under international human rights law States have an obligation to provide victims of human rights violations with adequate and appropriate remedies and to protect them from further harm. The provision of adequate remedies serves multiple purposes. It offers the victim payment or reparation for injury, loss or harm and is an essential element of access to justice. It helps to empower the victim, contributes to their recovery and reduces the risk of re-trafficking. At the same time, it serves as punishment and deterrence of traffickers'.

(Wijers 2014, p. 3)

The International Covenant on Civil and Political Rights (ICCPR), for example, requires States Parties to ensure "that any person whose rights or freedoms as herein recognized are violated shall have an effective remedy" (Art. 2(3)). A similar provision is found in Art. 13 of the European Convention on Human Rights (ECHR).

Empowerment is a valuable tool that should be addressed in the GR, but is an issue upon which the Concept Note is silent. It could for example have referred to Guideline 9 of the OHCHR Recommended Principles and Guidelines on Human Rights and Human Trafficking, which states:

'Trafficked persons, as victims of human rights violations, have an international legal right to adequate and appropriate remedies. This right is often not effectively available to trafficked persons as they frequently lack information on the possibilities and processes for obtaining remedies, including compensation, for trafficking and related exploitation. In order to overcome this problem, legal and other material assistance should be provided to trafficked persons to enable them to realize their right to adequate and appropriate remedies'.

The right to an effective remedy contains both substantive elements and procedural rights needed to be able to access remedies. According to the Basic Principles and Guidelines on Remedy and Reparation (United Nations 2006), these include: restitution, rehabilitation, compensation, satisfaction, and guarantees of non-repetition (Ngozi Ezeilo 2011). Yet, none of these are covered in the Concept Note.

We argue that these procedural rights include access to information about available remedies in a language the victim understands; the right to legal assistance, including to pursue compensation; the right to remain in the country during legal proceedings, including those for claiming compensation; protection against unlawful interference with the victim's privacy and safety from intimidation and retaliation before, during and after proceedings; the right to play a meaningful role in legal proceedings, to being heard and to act; and medical, psychological, social, administrative and any other assistance that they may require in order to exercise the right to an effective remedy in a meaningful manner (Wijers 2014). On these well-known Human Rights narratives the Concept Note is strangely silent.

\subsection{The (Dis) Embodiment of Sex Work}

The phrase 'sex work' does not appear in the draft document; this is controversial as the principle of non-discrimination is fundamental to the realisation of all human rights. All the human rights courts and international treaties uphold this general principle, including the Universal Declaration of Human Rights.

Many States exclude sex workers from protection against trafficking by wrongly considering consent to sex work as consent to abuse. The same may apply to (undocumented) migrants when they consented to carry false papers or carry out unauthorised work abroad. The Concept Note recreates this lack of protection, although according to the UN definition (2000), any recruitment or transport, by use of coercive or deceptive means should be treated as trafficking. The fact that a victim consented to migrate, to carry false documents, to work undocumented abroad, to do domestic work, pick berries or to do sex work, cannot be used to argue that the victim 'consented' to work in conditions of forced labour, slavery or servitude. The nature of the labour or services provided, 
including those in the sex industry, are irrelevant to the question of whether or not the victim's human rights are violated. In practice, the distinction between 'innocent' and 'guilty' victims is one of the major obstacles to combat trafficking effectively. As noted by the European Expert Group in its 2004 report (European Commission 2004):

'The effect is that in many cases, instead of the offender standing trial, it is the victim who has to prove her 'innocence', thus shifting the focus from the acts of the trafficker to the morality of the victim'.

The distinction between 'good' women who deserve protection and 'bad' women who forfeited their right to protection against abuse implies two unpalatable propositions. Firstly, that sex workers may be abused with impunity. This condones violence and abuse against sex workers, adds to the stigma and acts as a barrier for trafficked women to escape, no matter whether they were forced into sex work or entered sex work from their own decision. Secondly, that the right of women to be protected against violence and abuse is determined by their sexual purity or 'honour'. A stance that is deeply anti-feminist and not only harmful for sex workers, but for all women (Wijers 2015).

The problems attached to the distinction between so-called 'sexual exploitation' and 'labour exploitation' are not addressed at all in the Concept Note, yet the separation of sexual exploitation from forced labour falsely suggests that forced labour cannot exist in the sex industry. A consequence of this omission is to deprive sex workers of protection against the practice. In this regard it should be noted that the International Labour Organization (ILO) Committee of Experts has always constructed forced prostitution as a form of forced labour (ILO 2007; ILO 2017). As stated by the 2007 International Labour Conference:

'While a certain distinction has been drawn in the above definition between trafficking for forced labour or services and trafficking for sexual exploitation, this should not lead to a conclusion that coercive sexual exploitation does not amount to forced labour or services, particularly in the context of human trafficking'.

$$
\text { (ILO 2007, p. 42) }
$$

Despite an earlier distinction the Concept Note implicitly makes between trafficking and sex work, in practice the singling out of 'sex trafficking' reinforces the conflation of sex work and trafficking, denying women agency and leading states to combat sex work instead of trafficking. In addition, the distinction between 'sexual exploitation' and 'labour exploitation' gives rise to diametrically opposed strategies in combating trafficking in the sex industry and other industries (see Simmons and David 2012). In the latter case, strategies focus on strengthening rights of (migrant) workers and enforcing labour standards to combat abusive practices. Conversely, in the case of trafficking in the sex industry, the further criminalisation of prostitution is advocated in the document. This leaves sex workers with fewer instead of more rights and increases instead of decreases their vulnerability to abuse and exploitation. The document, moreover, excludes sex work from measures to address forced labour in other industries, such as those contained in the 2014 ILO recommendation for the suppression of forced labour (ILO 2014; Wijers 2015).

The concrete effects of policies and measures on the health, safety and rights of the groups affected in line with previous CEDAW's Concluding Observations (as analysed by Van den Brink and Wijers 2012) will need to be looked in within the General Recommendation. Caution is not heeded, however, in the Concept Note as regards criminal law and other repressive anti-trafficking strategies which risk increasing vulnerability to exploitation and abuse rather than protecting women against such practices (Pai et al. 2018).

\subsection{Disempowerment and Disregard of Labour Rights}

A focus on measures to empower women, enlarge rather than limit their options and improve the protection of their labour and human rights is also missing. Rather than ideologies, the actual 
impact of anti-trafficking laws, policies and measures on often already marginalised groups of women should be the main measure. The GR will also need to have as a leading principle that measures to address trafficking should not negatively impact on the health, safety and rights of trafficked persons and other groups affected by trafficking and/or anti-trafficking policies, in particular female migrants, sex workers, and refugees in line with Principle 3 of the 2002 Recommended Principles and Guidelines on Human Rights and Human Trafficking and the 2010 Commentary on the Recommended Principles and Guidelines on Human Rights and Human Trafficking of the OCHR (United Nations 2010). Yet the narrative in the Concept Note does not encompass these principles.

In addition, the need for participation and empowerment of trafficked persons and other groups affected by trafficking and anti-trafficking measures needs to be stressed. This means their involvement in the design, implementation, monitoring and evaluation of anti-trafficking measures, including the development of the General Recommendation. These are not only core human rights principles; they are an important safeguard for preventing undesirable negative side effects of anti-trafficking measures. Similarly important is the inclusion of the provision of resources to support people who sell sex, including those who want to leave sex work. Existing legislative and crime fighting resources are better focused to ensure improved protection of sex workers and the realisation of their human rights, including the right to be protected against violence and abuse, and to leave prostitution if they wish. Given that the GR is located in the textual context of the Concept Note, and in the Concept Note these narratives are silenced, it is hard to envisage how that might happen.

\section{Recommendations}

To conclude, our analysis has made explicit the documentary construction of the Concept Note and how it may frame the discursive acts that will follow with the General Recommendation. It therefore needs to be explicit that the GR should extend the right to protection, assistance and compensation to all victims of exploitation under forced labour or slavery-like conditions whether a victim of trafficking, a smuggled person, an undocumented migrant or a lawful resident. This should apply no matter how they arrived in that situation including other ways, e.g., debt bondage or inherited status. There is no reason why one category of victims of forced labour and slavery-like practices should have access to assistance and protection and others not, simply because of the way they arrived in that situation. As Wijers (2015) argues, to focus on the outcomes of trafficking, rather than on the means of trafficking shifts the debate from morality to actual working conditions. Ironically, this is what states are already obliged to do under Art. 8 of the Covenant on Civil and Political Rights and the Forced Labour conventions. Alternative constructions in policy would deny them justice.

To take account of the evidence to ensure the human rights of women and girls are upheld in the context of global migration, CEDAW will have to address these issues in the final version of the Recommendation on trafficking in women. In addition, we argue that, taken as a whole, the General Recommendation (GR) should include measures that ensure that anti-trafficking laws, policies and measures do not violate or undermine (women's) human rights, and that they are evidence-led and gender-sensitive rather than reproducing sector-specific gender stereotypes that dis-embody sex work and exclude transwomen and others. It needs to cover all forms of trafficking, including for domestic labour, care work, marriage and other female designated labour sectors, and should include in-border trafficking.

Author Contributions: B.B.-G. and M.W. wrote sections of a first draft. B.B.-G. integrated the sections, carried out further analysis, and revised the paper following peer review. A.J. provided overview, comments and proofing. An oral two-minute submission of some of the content of a previous version of the paper was presented by B.B.-G. to the United Nations on 22 February 2019. All authors have read and agreed to the published version of the manuscript.

Funding: None. Writing and submission of the manuscript was made possible, however, due to the paid sabbatical of the first author by Birkbeck, University of the London.

Conflicts of Interest: There are no conflicts of interest for any of the authors. 


\section{References}

Amnesty International. 2016a. Amnesty International Policy on State Obligations to Respect, Protect and Fulfil the Human Rights of Sex Workers. Available online: www.amnesty.org/en/documents/pol30/4062/2016/en/ (accessed on 2 December 2018).

Amnesty International. 2016b. The Human Cost of 'Crushing' the Market: Criminalization of Sex Work in Norway. Available online: https://www.amnesty.org/en/documents/eur36/4034/2016/en/ (accessed on 2 December 2018).

Anderson, Bridget, and Julia O'Connell Davidson. 2004. Trafficking: A Demand-Led Problem? Stockholm: Save the Children.

Atkinson, Paul, and Amanda Coffey. 2004. Analyzing Documentary Realities. In Qualitative Research: Theory Method and Practice. Edited by David Silverman. London: Sage.

Brooks-Gordon, Belinda. 2005. Clients and commercial sex: Reflections on 'Paying the Price: A Consultation Paper on Prostitution'. Criminal Law Review 6: 425-43.

Brooks-Gordon, Belinda. 2008. State violence towards sex workers. BMJ 337: 908. [CrossRef] [PubMed]

Brooks-Gordon, Belinda. 2010. Bellwether citizens: The regulation of male clients of sex workers. Journal of Law and Society 37: 145-70. [CrossRef]

Brooks-Gordon, Belinda. 2018. Into the Light: A Model for Justice for Workers' Rights in the Shadow and Gig Economy. In Realising Justice for Sex Workers. Edited by Sharron Fitzgerald and Kathryn McGarry. London: Rowman and Littlefield, pp. 183-202.

Brooks-Gordon, Belinda, Brian Paddick, Hannah Bettsworth, Sarah Brown, Charlotte Cane, Flo Clucas, Christopher Cooke, Simon Cordon, Sandra Hobson, Catrin Ingham, and et al. 2017. A Rational Approach to Harm Reduction. Liberal Democrats Policy Paper $126 . \quad$ Available online: https://d3n8a8pro7vhmx.cloudfront.net/libdems/pages/13634/attachments/original/1487768795/SW_ Policy_Paper_(Online).pdf?1487768795 (accessed on 2 February 2019).

CEDAW. 2018. Concept Note. Prepared for the Committee on the Elimination of Discrimination against Women on its Elaboration of a General Recommendation on Trafficking in Women and Girls in the Context of Global Migration. New York: CEDAW. Available online: https://www.ohchr.org/Documents/HRBodies/CEDAW/Trafficking/ ConceptNote.pdf (accessed on 2 February 2019).

Coffey, Amanda. 2004. Reconceptualizing Social Policy: Sociological Perspectives on Contemporary Social Policy. Buckinghamshire: Open University Press and McGraw Hill.

Coffey, Amanda. 2014. Analysing Documents. In The SAGE Handbook of Qualitative Data Analysis. Edited by Uwe Flick. Thousand Oaks: SAGE, pp. 367-79.

Day, Sophie, and Helen Ward. 2004. Sex Work, Mobility and Health in Europe. London: Kegan Paul.

DemandAt. 2017. Policy Brief. The Demand-Side in Anti-Trafficking: Current Measures and Ways Forward. Available online: http://demandat.eu/publications/policybriefs (accessed on 4 February 2019).

Dodillet, Susanne, and Petra Östergren. 2011. The Swedish Sex Purchase Act: Claimed Success and Documented Effects. Paper presented at International Workshop: Decriminalizing Prostitution and Beyond: Practical Experiences and Challenges, The Hague, The Netherlands, March 3-4.

Doezema, Jo. 2002. Who Gets to Choose? Coercion, Consent, and the UN Trafficking Protocol. Gender and Development 10: 20-27. [CrossRef]

ECATHB. 2005. Council of Europe Convention on Action against Trafficking in Human Beings. Available online: http://www.europarl.europa.eu/document/activities/cont/201006/20100607ATT75644/ 20100607ATT75644EN.pdf (accessed on 2 December 2018).

ECHR. 1950. European Convention of Human Rights and Fundamental Freedoms. Available online: https: //www.echr.coe.int/Documents/Convention_ENG.pdf (accessed on 2 December 2018).

European Commission. 2004. Report of the Experts Group on Trafficking in Human Beings. Brussels: European Commission, p. 51. Available online: http://lastradainternational.org/lsidocs/49\%20Report\%20of\%20the \% 20Experts\%20Group\%20on\%20Trafficking\%20in\%20Human\%20Beings.pdf (accessed on 2 February 2019).

Fairclough, Norman. 2001. New Labour New Language. London: Routledge.

Fuckförbundet. 2019. Twenty Years of Failing Sex Workers. A Community Report on the Impact of the 1999 Swedish Sex Purchase Act. Available online: http://www.sexworkeurope.org/sites/default/files/userfiles/files/ FF19\%20-\%20INTERACTIVE\%20\%281\%29.pdf (accessed on 17 December 2019). 
Global Alliance against Traffic in Women. 2007. Collateral Damage: The Impact of Anti-Trafficking Measures on Human Rights around the World. Bangkok: GAATW. Available online: https://gaatw.org/resources/publications/908collateral-damage-the-impact-of-anti-trafficking-measures-on-human-rights-around-the-world (accessed on 20 January 2019).

ICCPR. 1966. International Covenant on Civil and Political Rights. Available online: https://www.ohchr.org/en/ professionalinterest/pages/ccpr.aspx (accessed on 2 December 2018).

ICERD. 1965. International Convention on the Elimination of All Forms of Racial Discrimination. Available online: https://www.ohchr.org/en/professionalinterest/pages/cerd.aspx (accessed on 2 December 2018).

ICESCR. 1966. International Covenant on Economic, Social and Cultural Rights. Available online: https: //www.ohchr.org/en/professionalinterest/pages/cescr.aspx (accessed on 2 December 2018).

ICRSE. 2016. Surveilled. Exploited. Deported. Rights Violations against Migrant Sex Workers in Europe and Central Asia. Amsterdam: International Committee on the Rights of Sex Workers. Available online: http://www.sexworkeurope.org/sites/default/files/userfiles/files/ICRSE_Briefing\%20paper_ MIGRANTS\%20RIGHTS_November2016_A4_PRINT.pdf (accessed on 2 February 2019).

ICRSE. 2018. Policing and Detention of Sex Workers in Europe and Central Asia. Amsterdam: International Committee on the Rights of Sex Workers. Available online: http://www.sexworkeurope.org/news/newsregion/icrse-launches-new-resource-policing-and-detention-sex-workers-europe-and-central (accessed on 2 February 2019).

ILO. 2007. Eradication of Forced Labour. Geneva: International Labour Organisation, p. 42. Available online: https://www.ilo.org/wcmsp5/groups/public/---ed_norm/---relconf/documents/meetingdocument/ wcms_089199.pdf (accessed on 3 February 2019).

ILO. 2014. Forced Labour (Supplementary Measures) Recommendation. Report No. 203. Geneva: International Labour Organisation. Available online: http://www.ilo.org/dyn/normlex/en/f?p=NORMLEXPUB:12100:0:: NO::P12100_INSTRUMENT_ID:3174688 (accessed on 2 February 2019).

ILO. 2017. Global Estimates of Modern Slavery, Forced Labour and Forced Marriage. Available online: https:// www.ilo.org/global/publications/books/WCMS_575479/lang--en/index.htm (accessed on 26 December 2019).

Levy, Jay. 2014. Criminalising the Purchase of Sex: Lessons from Sweden. London: Routledge.

Levy, Jay, and Pye Jacobsson. 2014. Sweden's abolitionist discourse and law: Effects on the dynamics of Swedish sex work and on the lives of Sweden's sex workers. Criminology E Criminal Justice 14: 593-607.

Mai, Nicola, Calogero Giametta, and Helene Le Bail. 2018. The Impact of the 'Swedish Model' in France: Chronicle of a Disaster Foretold. Available online: https://www.opendemocracy.net/beyondslavery/nicola-mai-calogerogiametta-h-l-ne-le-bail/impact-of-swedish-model-in-france-chronicl (accessed on 2 February 2019).

Ngozi Ezeilo, Joy. 2011. Report of the UN Special Rapporteur on Trafficking in Persons, Especially Women and Children. (A/HRC/17/35). Available online: https://www.ohchr.org/en/issues/trafficking/pages/ traffickingindex.aspx (accessed on 2 February 2019).

OHCHR. 2019. Convention on the Elimination of All Forms of Discrimination against Women. New York: OHCHR. Available online: https://www.ohchr.org/EN/ProfessionalInterest/Pages/CEDAW.aspx (accessed on 17 December 2019).

Östergren, Petra. 2017. Preventing Exploitation and Trafficking in the Sex Work Sector. Brussels: European Commission. Available online: https://www.demandat.eu/publications/european-policy-brief-preventing-exploitationand-trafficking-sex-work-sector (accessed on 23 January 2019).

Pai, Aarthi, Laxmi Murthy, Meena Saraswathi Seshu, and Rakesh Shukla. 2018. Raided. How Anti-Trafficking Strategies Increase Sex Workers Vulnerability for Exploitative Practices. Borivali: Sangram, Vamp. Available online: https://www.sangram.org/resources/Raided-Book.pdf (accessed on 2 February 2019).

Phipps, Alison. 2017. Sex wars revisited: A rhetorical economy of sex industry opposition. Journal of International Women's Studies 18: 306-20.

Platt, Lucy, Pippa Grenfell, Rebecca Meiksin, Jocelyn Elmes, Susan G. Sherman, Teela Sanders, Peninah MwangiI, and Anna-Louise Crago. 2018. Associations between sex work laws and sex workers' health: A systematic review and meta-analysis of quantitative and qualitative studies. PLoS Medicine 15: e1002680. [CrossRef] [PubMed]

Prior, Lindsay. 2008. Repositioning Documents in Social Research. Sociology 42: 821. [CrossRef]

Prior, Lindsay, David Hughes, and Stephen Peckham. 2012. The Discursive Turn in Policy Analysis and the Validation of Policy Stories. Journal of Social Policy 41: 271-89. [CrossRef] 
Scambler, Graham, and Paoli Frederique. 2008. Health Work, Female Sex Workers and HIV/AIDS: Global and local dimensions of stigma and deviance as barriers to effective interventions. Social Science and Medicine 66: 1848-62. [CrossRef] [PubMed]

Simmons, Frances, and Fiona David. 2012. The road to effective remedies: Pragmatic reasons for treating cases of "sex trafficking" in the Australian sex industry as a form of "labour trafficking". Anti-Trafficking Review. [CrossRef]

United Nations. 2000. Protocol to Prevent, Suppress and Punish Trafficking in Persons Especially Women and Children, Supplementing the United Nations Convention against Transnational Organized Crime. Adopted by General Assembly resolution 55/25 of 15 November 2000. New York: United Nations.

United Nations. 2006. Basic Principles and Guidelines on the Right to a Remedy and Reparation for Victims of Gross Violations of International Human Rights Law and Serious Violation of International Humanitarian Law. Adopted by the General Assembly 21 March, A/RES/60147. New York: United Nations.

United Nations. 2010. Office of the High Commissioner for Human Rights. Recommended Principles and Guidelines on Human Rights and Human Trafficking. Commentary. Available online: https://www.ohchr. org/Documents/Publications/Commentary_Human_Trafficking_en.pdf (accessed on 2 February 2019).

UNODC. 2018. Global Report on Trafficking in Persons. New York: United Nations. Available online: https: //www.unodc.org/documents/human-trafficking/2019/GLOTiP_2018_BOOK_web_small.pdf (accessed on 2 December 2018).

Van den Brink, Marjolein, and Marjan Wijers. 2012. Because to me a woman who speaks in public is a public woman, 30 years Women's Convention and the struggle to eliminate discrimination of women in the field of trafficking and prostitution. In The Women's Convention Turned 30. Edited by Ingrid Westendorp. Maastricht: Maastricht Centre for Human Rights, Cambridge: Intersentia.

Wijers, Marjan. 2014. Paper Compensation of Victims of Trafficking under International and Dutch Law. The Hague: Netherlands Helsinki Committee.

Wijers, Marjan. 2015. Purity, Victimhood and Agency: Fifteen years of the UN Trafficking Protocol. Anti-Trafficking Review 4: 56-79.

Wijers, Marjan, and Lin Lap-Chew. 1999. Trafficking in Women, Forced Labour and Slavery-Like Practices in Marriage, Domestic Labour and Prostitution. Utrecht: Foundation against Trafficking in Women, Bangkok: Global Alliance against Traffic in Women. Available online: http://lastradainternational.org/lsidocs/1137-Trafficking\%20in\% 20women\%20Wijers-Lap\%20Chew.pdf (accessed on 3 January 2020).

(C) 2020 by the authors. Licensee MDPI, Basel, Switzerland. This article is an open access article distributed under the terms and conditions of the Creative Commons Attribution (CC BY) license (http://creativecommons.org/licenses/by/4.0/). 